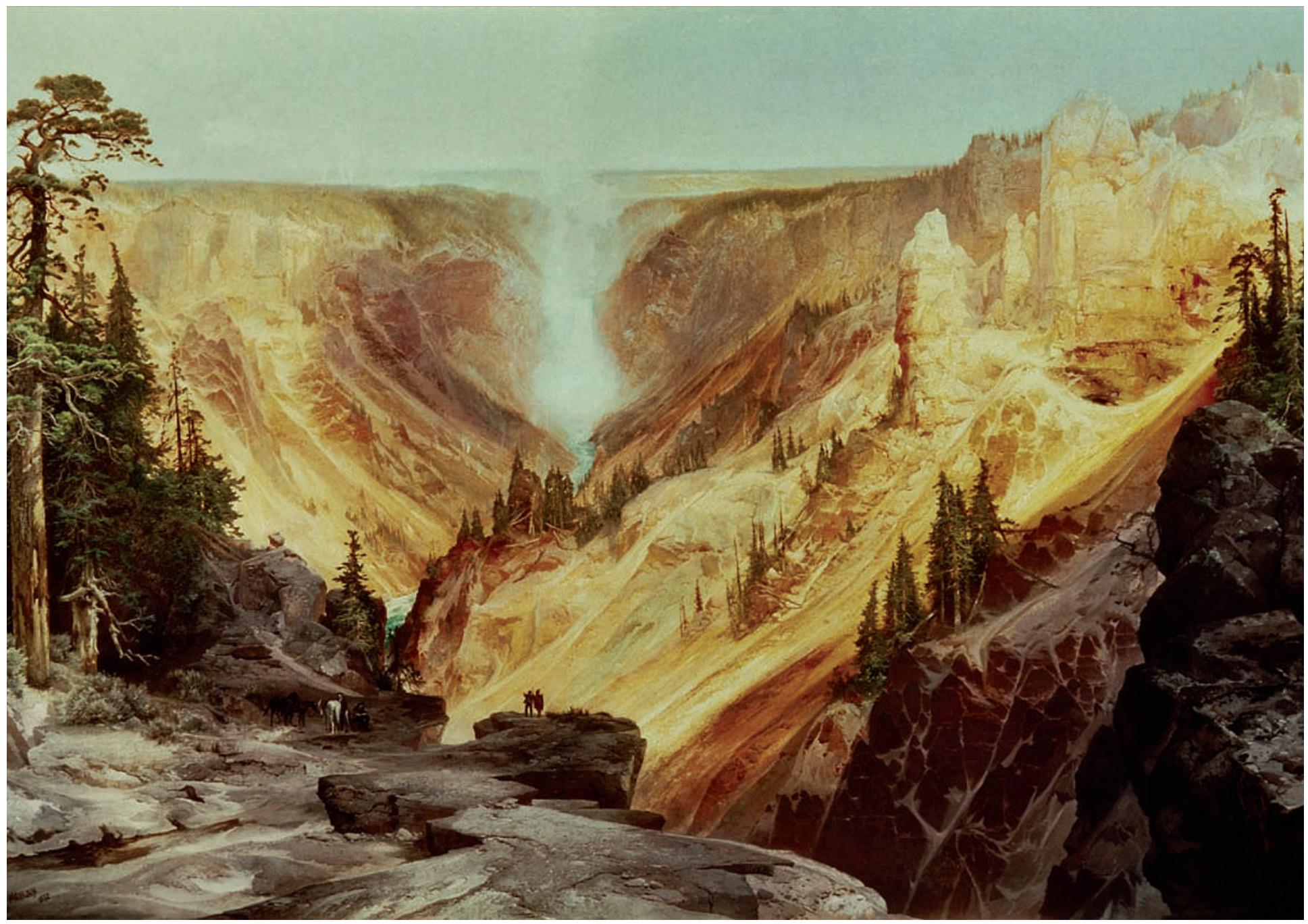

\title{
THE END OF THE WILD
}

BY EMMA MARRIS

Climate change means that national parks of the future won't look like the parks of the past. So what should they look like?

$\mathrm{I}$ magine Montana’s Glacier National Park without glaciers; California's Joshua Tree National Park with no Joshua trees; or the state's Sequoia National Park with no sequoias. In 50 years' time, climate change will have altered some US parks so profoundly that their very names will be anachronisms.

Jon Jarvis, who became director of the US National Park Service in 2009, has called climate change "the greatest threat to the integrity of our national parks that we have ever experienced". The sentiment represents a dramatic shift from the position held during the Bush administration, when officials refused to fully acknowledge

the existence of climate change. Now, park managers in the United States and around the world are working with researchers to map how the landscapes they care for might change. And they are coming to terms with the idea that the historical remit of most parks systems - to preserve a piece of land in its 'natural' state is untenable. "You can't fight the climate," says Ken Aho, an ecologist at

DNATURE.COM To hear more on options for managing Yellowstone, visit: go.nature.com/ya6k7y Idaho State University in Pocatello, who studies non-native species at Yellowstone National Park in Wyoming. "Eventually 
The Grand Canyon of Yellowstone by Thomas Moran (1872).

you have to throw up your hands," he says.

Nowhere is attachment to historical fidelity more pronounced than at Yellowstone, the first US national park and the best example of the park as a landscape seemingly unchanged by the passage of time. Visiting it, one crosses paths with bison and wolves. It is not hard to imagine a party of explorers coming around the next bend.

Much of Yellowstone's 900,000 hectares are high plateau, crossed by rivers and dotted with geothermal basins featuring pools and geysers. The park was created in 1872 , to protect the geological wonders and safeguard a wild landscape emblematic of the American west. Since 1916, Yellowstone and the nation's other parks and monuments have been run by the National Park Service, which has aimed to preserve the land in its 'natural' condition - typically meaning how it looked before white people arrived. In the words of the influential Leopold Report of 1963: "A national park should represent a vignette of primitive America." (A. S. Leopold et al.Wildlife Management in the National Parks Advisory Board on Wildlife Management; 1963.)

But Yellowstone can no longer be kept as it was in 1872, if that were ever possible. Climate change has already begun to transform the park (see 'Under attack'). The Yellowstone area has been plagued by tree pests, abetted by warmer temperatures. Fires are expected to become more frequent, animal populations are shifting and the landscape and ecology are being reshaped. Similar stories are playing out at all of the nation's parks, and the Park Service is beginning to react. In September 2010, it released a Climate Change Response Strategy, which includes sections on science, adaptation, mitigation and communication (National Park Service Climate Change Response Program; 2010). The report hints that climate change may force the Park Service to change the way it defines its mission. Maintaining a natural state can no longer be the goal, or important tools for adaptation, such as moving species or selective breeding, would be forbidden. And besides, that battle may already be lost.

\section{ENCROACHING DAMAGE}

A drive through the greater Yellowstone area reveals changes to the landscape. Most striking are the acres of trees standing dead, killed by an insect the size of a grain of rice. Mountain pine beetles, native parasites, burrow into and reproduce in the living wood of the trees. Winter temperatures of $-40^{\circ} \mathrm{C}$ kill the beetles, keeping their numbers down. But warm winters in the past ten years have allowed them to proliferate. More than half of the greater Yellowstone ecosystem's conifer forest has seen pine-beetle damage, and $10 \%$ of the forest has a 'high severity' infestation, in which more than $40 \%$ of trees are lost. Throughout the western United States,

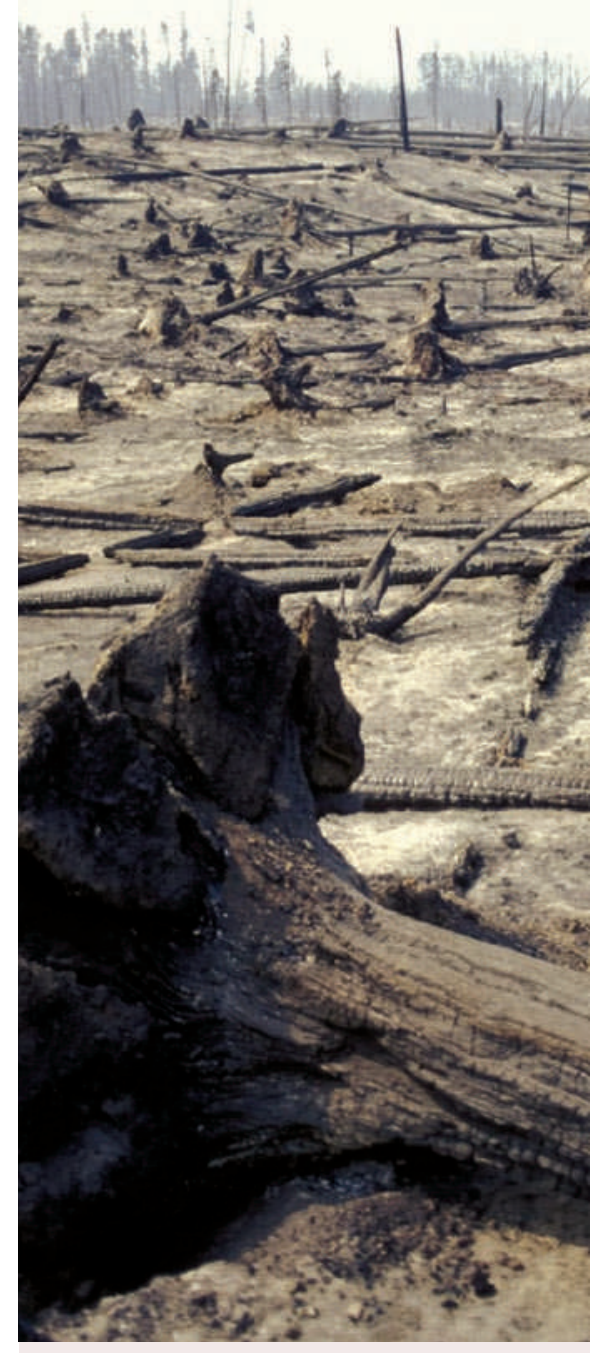

\section{UNDER ATTACK}

Climate change may increase the frequency of intense fires similar to the historic 1988 blaze (above) and may promote destruction of the trees by mountain pine beetles (bottom), which flourish in rising temperatures (graph).
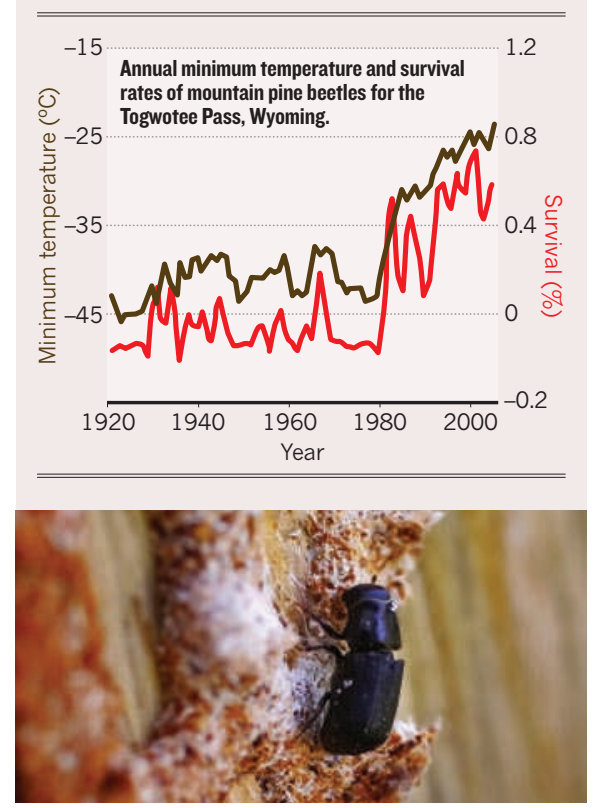

the Park Service has used insecticides to protect some trees, and removed a few dead ones. Mostly, however, it can only watch as an orange wave of dying trees ripples through the forest.

The dried-out remains left in the beetles' wake look like an invitation to intense forest fires that would reshape the landscape even more, but that is not necessarily the case. Monica Turner, an ecologist at the University of Wisconsin-Madison, has been modelling big blazes at Yellowstone, such as the inferno of 1988 that burned 321,000 hectares of forest. She and her colleagues have found that such fires burn in the living crowns of trees and don't rely on dead wood; furthermore, pine-beetle attacks kill trees, decreasing the amount of wood in an area and creating gaps that can stop a fire.

Even so, Turner's group expects that the big fires that typically occur every few hundred years might happen more frequently in the future without the beetles' help, thanks to increased temperatures and changes in precipitation levels. That increased frequency might turn some parts of Yellowstone into a landscape of young forests, with less capacity than more mature ones to absorb carbon dioxide from the atmosphere. This could potentially turn the park at large from a carbon sink into a carbon source.

But forecasting the future is complicated. Pines that don't get caught in a blaze may actually grow better in a warmer future; growth of lodgepole pines is limited by the length of the growing season and by cold temperatures. Meanwhile, species such as the larch, currently confined to lower altitudes than those at Yellowstone, may move up as temperatures rise.

Other familiar tree species might go locally extinct. Whitebark pine, a high-altitude species, is facing a three-way attack from pine beetles, a fungal disease called blister rust and climate change. As Yellowstone's peaks heat up, the tree's range is expected to move upslope, but the higher it goes the less area it will have. "The future of whitebark pine in Yellowstone is questionable," says Turner.

Ecosystems won't move predictably. "Migration in response to climate change can often be extremely messy," says Stephen Gray, a climatologist at the University of Wyoming in Laramie, who is among those working on scaling down global climate models to forecast changes at the level of individual parks.

As ecologists scramble to predict changes, park managers are gearing up for a new management style, which will have to include at least one of two approaches traditionally anathema to the profession: letting things change, or intervening aggressively to keep them the same. In many cases, choosing between these strategies will be the challenge.

If managers choose the former, they will need to create an environment conducive to change. For example, many conservation biologists argue for creating and maintaining corridors that connect parks to other natural areas. The bigger the connected area, the more room 
plants and animals will have to move and the larger the gene pools available for adaptation.

Wolverines are one species that might benefit. Maps of future climates suggest that by 2040, lower-elevation parts of their current range may no longer have the deep spring snow that wolverines need to make their dens. So managers should perhaps focus on increasing the quality and connectivity of land in the Colorado Rocky Mountains, California’s Sierra Nevada and parts of Wyoming and Utah to make sure that the wolverine population remains large enough to be genetically healthy.

To maintain corridors in areas that fall outside national-park remits, the Park Service is participating in Landscape Conservation Cooperatives, an initiative begun in September 2009. These clubs of federal and state agencies, conservation organizations, university scientists and other interested parties focus on managing huge chunks of land as units, rather than having every park, forest and piece of private land managed independently.

\section{A FIRM HAND}

But tough choices loom in terms of how much to meddle. Aggressive intervention might be needed to conserve some of Yellowstone's larger mammals (see 'Four seasons of worry for the grizzly') and its iconic trees. To preserve the whitebark pine, some scientists from various agencies have begun identifying trees that are resistant to blister rust and collecting seeds to breed rust-resistant trees. They've also begun planting whitebarks in newly burned areas. They plan to use insecticides to protect individual trees from pine beetles, prune off infected branches and thin the vegetation around the trees to give them a competitive advantage. They also plan to stop fires from burning rust-resistant or particularly genetically diverse stands of whitebarks. Some of these planned actions sound a lot like landscape gardening.

The alternative approach would be to let the whitebarks die out in Yellowstone, and plant them somewhere where they might flourish in a warmer future. Sally Aitken, a forest geneticist at the University of British Columbia in Vancouver, Canada, has planted whitebarks beyond their current range, in northwestern British Columbia. They seem to like it there.

Jarvis has suggested the possibility of moving species outside their native ranges to give them a better chance of surviving - just not right away. "The big point here is that we are willing to face these questions," he says. "We are not afraid to talk about them."

Other countries have ditched 'naturalness' for goals that encompass a range of acceptable states, and don't rule out aggressive intervention. Parks Canada uses an 'ecological integrity' approach, preserving a configuration of local flora and fauna that is likely to be robust.

At a conference on the Yellowstone ecosystem last October, many speakers talked about managing for 'resiliency' rather than historical

\section{SPECIES MANAGEMENT}

\section{FOUR SEASONS OF WORRY FOR THE GRIZZLY}

Grizzly bears can take the heat. If temperatures go up by a few degrees in Yellowstone National Park in Wyoming, they will just shed a little hair. But other changes might put the beasts to the test in a warmer future. Their movements tend to revolve around a few food sources spread out over the year - several of which are threatened by climate change and exotic species.

In spring, bears emerge from their dens and line the streams feeding Yellowstone Lake, looking for cutthroat trout that are migrating upstream to spawn. These days, the bears sometimes fish in vain. Introduced lake trout are eating the cutthroat trout, and lake trout stay in the lake to spawn.

In summer, grizzlies gorge on army cutworm moths found on high-altitude rocky slopes in Yellowstone. "A grizzly can eat about half its energy needs for the year in about 30 days of foraging on moths," says Hillary Robinson, an ecologist in Bozeman, Montana. If climate change dries up the wet microhabitats that the moths prefer or reduces the populations of prairie flowers that the caterpillars feed on, Yellowstone's grizzlies will feel the pinch.

By autumn, whitebark-pine seeds, thoughtfully collected into caches by squirrels, are a favourite food for grizzlies. But whitebarks are declining owing to an introduced fungus and an outbreak of mountain pine beetles that has been blamed on climate change. Roughly $82 \%$ of whitebark stands in the greater Yellowstone area are dead or dying.

Problems continue in late autumn and winter, when grizzlies that haven't yet gone into hibernation go looking for elk and other ungulates killed by the harsh conditions. If winters mellow, there may be fewer behind a trend of more bears leaving the park in winter and feeding on hunters' gut piles in recent years.

As if that weren't enough, Hank Harlow, a bear physiologist at the University of Wyoming in Laramie, is worried that warm carcasses. This shortage of meat may be

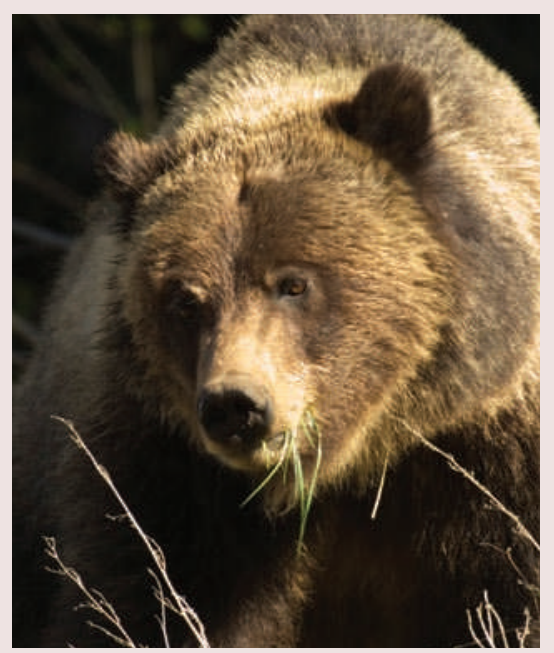

winters will rouse hibernating bears, reducing the time they spend in energysaving sleep. The energy expended on waking up could eat into the 5 kilograms of fat that females need to birth and nurse a pup during hibernation.

Park managers fear that as their food sources wane, bears will roam into the human environment, looking for hunters' kills, sheep and refuse. Many will be shot; humans are a leading cause of death for the bears. "Everywhere they go outside of public land there is the urban, human interface," says Mark Haroldson, a biologist with the Interagency Grizzly Bear Study Team at the US Geological Survey in Bozeman. "It is a minefield for them."

If climate change and human pressure reduces the food available until the land can no longer support a viable bear population, Yellowstone's managers may have to decide between letting grizzlies go and feeding them - an option at odds with attempts to maintain the park as a wilderness.

"Feeding bears just bothers me," says Leigh Welling, the Climate Change Response manager for the US National Park Service. But, she adds, "I don't think we would close the door on it". E.M.

fidelity, promoting an ecosystem's ability to change with the times without changing in character. Rather than trying to sustain a stressed ecosystem that collapses at the first hot summer, the idea is to let things change gracefully.

But the Park Service isn't planning to change its mission any time soon. "I don't think resilience replaces our current management foundation," says Jarvis. "Our goal has never been to freeze [parks] in some kind of stasis."

Resiliency may be achievable for Yellowstone, even if it won't look like it did in 1872 . Whitebark pines may not make it, but lodgepole pines are very resilient. Bears and wolves are clever. Yellowstone is big and Yellowstone is tough.

"As a scientist who really treasures the region," says Turner, "I believe that Yellowstone will go on in the face of climate change. Yellowstone is very resilient. The 1988 fires are not a catastrophe. Bark beetles are not a catastrophe." - SEE EDITORIAL P.131

Emma Marris writes for Nature from Columbia, Missouri. 
Gene reading steps up a gear

\section{Third-generation sequencing machines promise to make their mark one molecule at a time.}

\section{BY HEIDI LEDFORD}

CCT's t's super cool, but it's never going to work," genomics guru Eric Schadt responded when a wary investor asked for his opinion about a new DNA-sequencing technology in 2003. A company was creating a machine that it claimed could revolutionize the field by reading over the shoulder of an enzyme as it copied DNA molecules.

Despite his initial scepticism, Schadt touted the method's success last weekend at the Advances in Genome Biology and Technology meeting in Marco Island, Florida. Now chief scientific officer at the company he had once doubted - Pacific Biosciences in Menlo Park, California - Schadt was one of several researchers at the meeting who provided a glimpse of how the company's first DNAsequencing machines are performing.

All eyes are on these machines. Pacific Biosciences set a high bar for its own success in 2008, when chief technology officer Stephen Turner boasted that the instruments would be able to sequence a human genome in just 15 minutes by 2013, compared with the full month it took at that time. This year, as researchers unveiled data from the first machines to leave the company's campus, the discussion was less about revolutionizing the field and more about niche applications.

After several delays, customers have now been told to expect their machines in the second quarter of this year.

The machines potentially offer advantages over the 'next-generation' sequencers currently on the market. Users of the
"Single molecule is the future of sequencing, but it still has hurdles." new machines last week reported generating sequences an average of 1,500 base pairs long - about ten times the length of those currently produced by the state-of-the-art sequencers from Illumina in San Diego, California. These longer reads make it easier to stitch fragments of DNA sequences together into a coherent genome sequence.

Pacific Biosciences' machines are also fast. In a paper published online in December, Schadt and his team used them to trace the origin of the ongoing cholera outbreak in Haiti by sequencing the genomes of five strains of Vibrio cholerae (C. S. Chin et al. N. Engl. J. Med. 364, 33-42; 2011). The team sequenced all five strains in less than an hour. It takes about a week to complete a 150-base sequencing run

\section{INAFLASH}

New DNA sequencers watch an enzyme called DNA polymerase as it uses fluorescently tagged bases to synthesize DNA. Each base is identified by a distinguishing colour that flashes as the base is incorporated into the DNA strand.

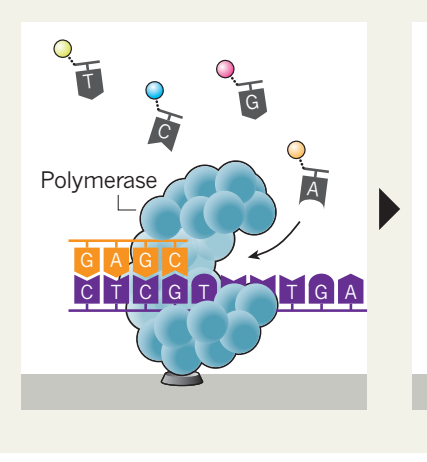

on an Illumina sequencer.

But for many researchers, the key advance of the Pacific Biosciences machines is the ability to sequence single molecules of DNA. The instruments work by watching as an enzyme confined within a tiny compartment copies DNA, adding fluorescently labelled bases that flash with characteristic colour as they are added to the DNA strand (see 'In a flash'). Leading sequencers on the market instead report an average sequence taken from a population of molecules.

Single-molecule sequencing opens the door to analysing rare sequence variants, and frees researchers from having to amplify DNA samples before sequencing - a step that can introduce errors, and can fail altogether for certain DNA sequences. "Single molecule is the future of sequencing," says Michael Metzker, who studies sequencing technology at Baylor College of Medicine in Houston, Texas. "But it still has hurdles."

Chief among those hurdles has been high error rates. Whereas other methods on the market surpass $99 \%$ accuracy, users of the Pacific Biosciences machines last week reported an accuracy rate of about $85 \%$. Schadt argues that this can be overcome by resequencing the same molecule repeatedly.

Nevertheless, because of the cost of its machines (US\$700,000 per unit compared with less than $\$ 125,000$ for the new Illumina sequencer rolling out this autumn) and limits on the number of sequences that can be read during every run, the instruments are unlikely

\section{DNATURE.COM}

See our human genome special at: go.nature.com/ugle4l to disrupt the sequencing market in the near future. For now, the machines are likely to be used for tackling regions of the human genome that resisted conventional sequencing. The instruments can also detect some chemical modifications to DNA, which could be useful to the burgeoning epigenetics field. Peter White, who heads the sequencing centre at Nationwide Children's Hospital in Columbus, Ohio, says he is interested in acquiring a machine, but would mainly use it to analyse microbial genomes, which tend to be much smaller than mammalian genomes.

At the meeting last week, Turner did not reiterate his pledge for a 15-minute human genome. But he did emphasize that there is still plenty of room for the current instrument to improve. "We are just at the beginning of this technology." -

\section{CORRECTIONS}

The News story 'Social science lines up its biggest challenges' (Nature 470, 18-19; 2011) should have said that Nick Nash did his MBA at Stanford University.

The News Feature 'Exoplanets on the cheap' (Nature 470, 27-29; 2011) should have said that the spectrometer on which the comb at the Hobby-Eberly Telescope was mounted came from Pennsylvania State University not the University of Pennsylvania.

The graph in the News Feature 'The End of the Wild' (Nature 469, 150-152; 2011) showing a correlation between rising minimum temperatures in Wyoming and increased survival rates for mountain pine beetles should have made it clear that the beetle data were modelled not measured. 